\title{
Closed Loop DC-DC Boost Converter with Inverter for Small Scale Generation Plant
}

\author{
Manish Agarwal ${ }^{1}$, Sanjeev Gupta ${ }^{2}$, Sudhir P.Phulambrikar ${ }^{3}$ \\ ${ }^{1}$ PG student \& Electrical \& SATI Degree, Vidisha, India \\ ${ }^{2}$ Associate Professor \& Electrical \& SATI Degree, Vidisha, India \\ ${ }^{3}$ Associate Professor \& HOD \& Electrical \& SATI Degree, Vidisha, India
}

\begin{abstract}
In this paper implements the single phase two level PWM inverter by using DC converter. DC voltage is boosted using de to dc boost converter with the help of close loop topology. Here converter will be used to convert 24 volts DC voltage to 373 volts. The boosted DC voltage is converted in to AC with help of PWM inverter. Boosted DC voltage is fed with the inverter and that converts $\mathrm{DC}$ voltage into $\mathrm{AC}$ voltage. The cascaded $\mathrm{H}$-Bridge type of inverter is used to achieve AC output voltage. The output of inverter is given to low-pass filter which will give 260 volts (RMS) AC, $50 \mathrm{~Hz}$ pure sinusoidal output voltage \& finally this output is given to the load.
\end{abstract}

Key words: H-Bridge Inverter, Closed Loop DCDC Boost Converter, Pulse Width Modulation

\section{Introduction}

A DC-DC Boost converter converts 24 volts DC voltage to fixed $373 \mathrm{~V}$ DC voltage with the help of close loop phenomenon.

This DC voltage is converted to AC voltage by using two level inverter the inverter gives 260 volt RMS AC voltage. This overall performance is also called "Distribution side generation".

A distributed power unit can be connected directly to the consumer or to utilities transmission or distribution. Figure-1 shows a basic block diagram for the scheme of DC-DC Boost converter with Inverter for small scale plant.

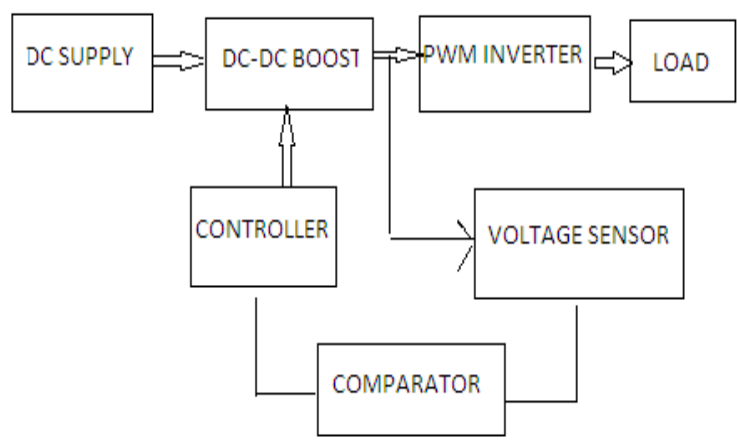

Fig-1 Block diagram of schemetic scheme

In the block diagram we see the DC supply given to the DC-DC boost converter and the output of DC -DC boost converter given to the PWM inverter which converts the output of converter inform of AC . The Inverter output is given to the load which gives the final output which is feedback to the closed loop phenomenon.

\section{Simulation modeling}

DC-DC Boost converts 24 volt DC input voltage to 370 volt DC output voltage.

This DC voltage given to the two level PWM inverter which converts the converter output in the form of 260 volt (RMS) AC voltage.

- Boost converters are step-up power converters that take in a low voltage input $\&$ provide an output at a much higher voltage.

- The internal operations of a boost converter can be thought of as a charge storage \& 
transfer mechanism. There are two states $\mathrm{ON} \& \mathrm{OFF}$.

The variation in input DC supply is corrected by using closed loop phenomenon.

\subsection{Working of boost converter}

The continuous conduction mode of a boost converter assumes two states for each switching cycle. Figure- 2 shows the boost converter circuit.

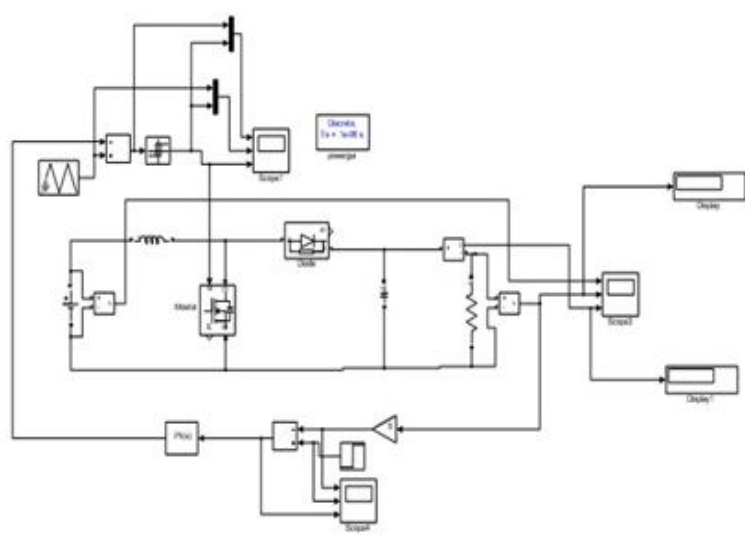

Fig- 2 Modal diagram of Closed loop boost converter

1. When in the 'ON' state MOSFET will be $\mathrm{ON} \&$ diode will be $\mathrm{OFF}$.

2. In the 'OFF' state MOSFET will be OFF \& diode will be ON.

\subsection{Single phase H- Bridge inverter}

The two level PWM inverter circuit is used to convert the converter DC output in to AC output. The figure3 shows the two level inverter scheme with PWM handling process.

$373 \mathrm{v}$ dc voltage comes in to the inverter, which is cascaded with converter, is converted in to the 373 AC voltage. When the Switch T1 and T2 is "ON" the inverter gives the perform in positive half cycle and for negative half cycle switch $\mathrm{T} 3$ and $\mathrm{T} 4$ will "ON", at this time switch T1 and T2 will "OFF".

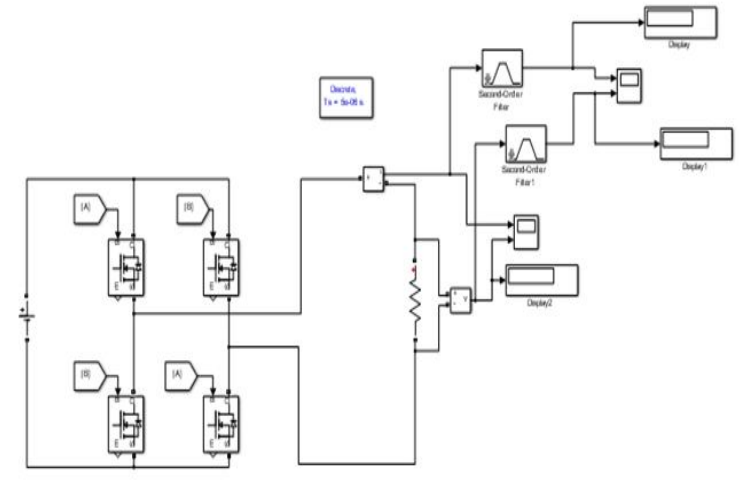

Fig-3 Single phase H-Bridge inverter

The filters are used to improve the controllability and the efficiency of the circuit. Basically the active power filter is used, Because it minimize the low frequency current harmonics while high pass units have been connected to attenuate the amplitude of high frequency current components.

\subsection{Closed loop DC-DC boost connected inverter}

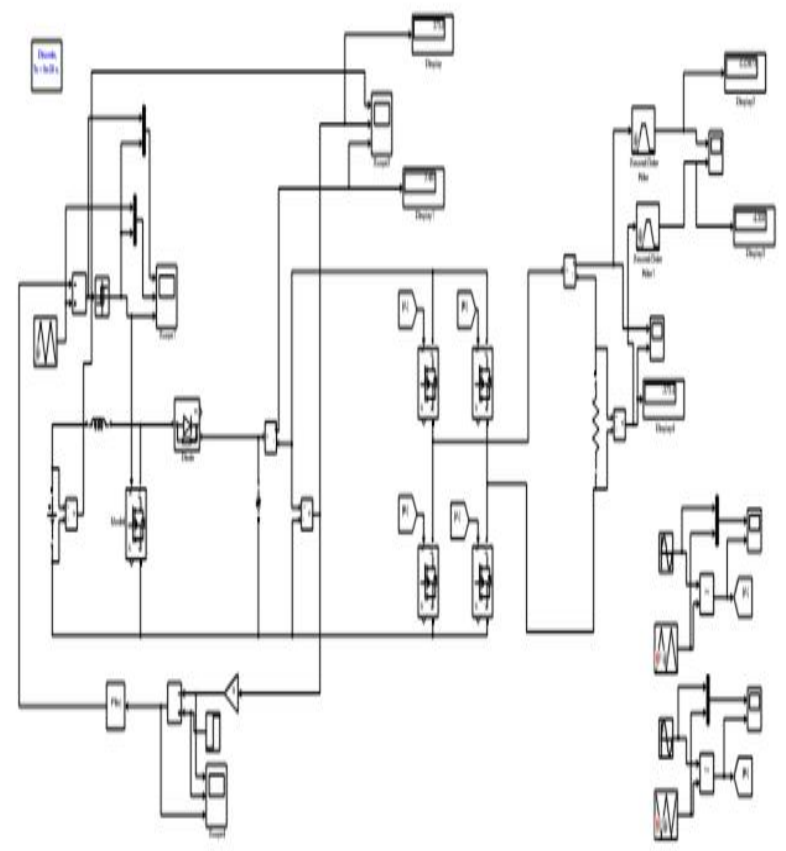

Fig-4 Closed loop DC-DC boost connected inverter model 
Inverter is directly connected with the close loop dcdc boost converter. The circuit operates when the boost circuit get a input power of $24 \mathrm{~V}$ dc source \&it gives output voltage of $373 \mathrm{~V} \mathrm{dc}$ and which is directly connected with the inverter to get $260 \mathrm{~V}$ (RMS) ac voltage waveform.

\section{Results analysis}
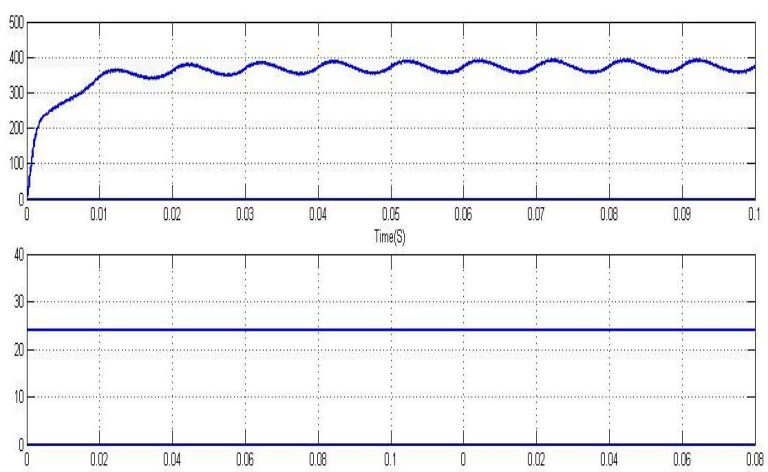

Fig-5 Output of boost converter

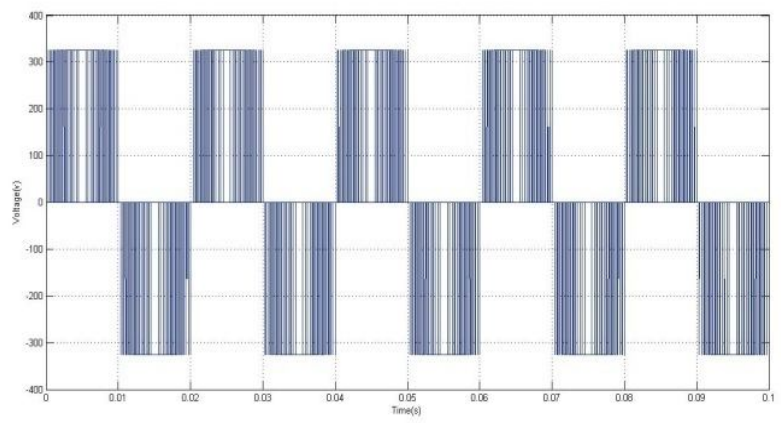

Fig- 6 Output voltage of inverter

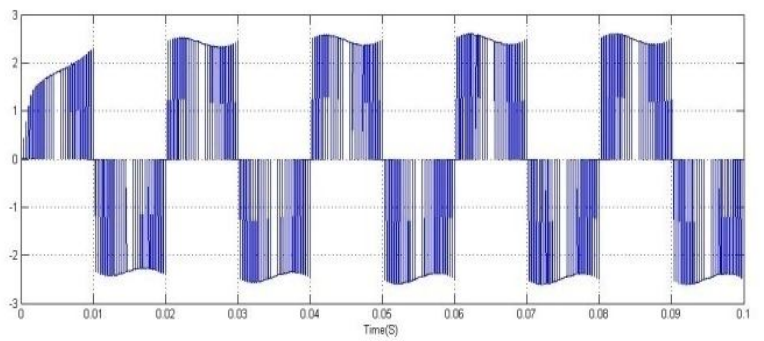

Fig-7 Output current waveform

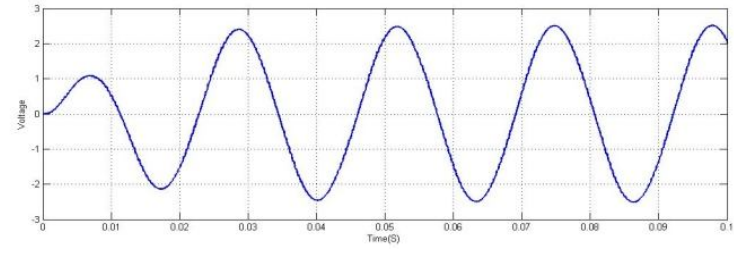

Fig- 8 Output current waveform(with filter)

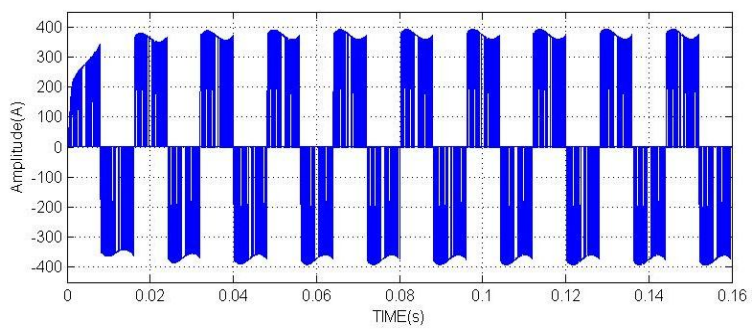

Fig- 9 Output voltage waveform (without filter)

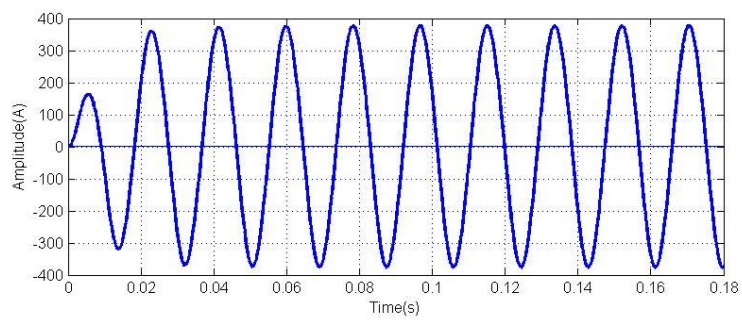

Fig. 10 output voltage waveform (with filter)

\section{$\underline{\text { 4.Conclusion }}$}

Cheap fast \& Efficient switching converters \& inverters are in high demand in the high-tech world. For varying needs \& specifications engineers are expected to design reliable \& unique solutions. Safety cost $\&$ size of each design is also a priority in today's industrialist economy.

This work presents simulation of closed loop controlled DC-DC boost converter with inverter system for small scale generation plant application.

Matlab model for close loop dc-dc boost converter gives 373V boost voltage from $24 \mathrm{~V}$ input Dc supply.

we kept output DC voltage constant \& get desired output results from the inverter ie $373 \mathrm{~V} \mathrm{AC}$. 
Single phase dc-dc closed loop boost connected inverter is low cost compact in size \& easy to install.

The largest difference is found in the boost voltage out put respect to input is better than previous work results.

\section{REFERENCES}

1.Vimal M. Vaniya, Jaydeep G. Gajipara Prof. Jayanti A. Jadav "Single Phase PWM Inverter With Close Loop Dc-Dc Boost Converter For Solar Application" International Journal of Engineering Research \& Technology (IJERT) Vol. 2 Issue 5, May - 2013 ISSN: 2278-0181

2.Tarak Salmi*, Mounir Bouzguenda**, Adel Gastli**, Ahmed Masmoudi* "MATLAB/Simulink Based Modelling of Solar Photovoltaic Cell" international journal of renewable energy research tarak salmi et al., vol.2, no.2, 2012

3.German Advisory Council on Global Change WBGU Berlin 2003 www.wbgu.de; Renewable Energy Policy Network for the21st Century Renewable Global Status Report 2006.

4.Distributed Power Coalition of America. "What is Distributed Power?" http://www.distributedgeneration. com/dpca/what.html.

5.Converter's Power Stage Low Power DC/DC Application by Brigitte Hauke"Analysis of Boost Converter Using PI Control Algorithms" Mitulkumar R. Dave \&K.C. Dave.

6. "power electronics"(sinusoidal pulse width modulation) K.B.. hanchandani second edition page no:557. 